\title{
Awareness on Early Marriage among Adolescent Girls in Selected Rural Area of Bangladesh
}

\author{
Lobaba Sultana Lima* \\ Master of Public Health, American International University, Bangladesh
}

Submission: July 19, 2018; Published: July 30, 2018

*Corresponding author: Lobaba Sultana Lima, Master of Public Health, American International University Bangladesh, Bangladesh, Email: bjnd18@gmail.com

\begin{abstract}
Early marriage is a curse for girl. In addition to this country like Bangladesh has to deal this issue cautiously and immediately. This crosscut survey like study was an attempt to assess awareness level of early marriage among adolescent girls in selected rural area of Bangladesh. Non-probability convenient sampling was used to collect sample of 300 girls. For each correct answer the score was one. Then accordingly the respondents were categorized in different groups as below: Good $=$ Score $\geq 3$, Fair $=$ Score 2, Poor $=$ Score 1. Half of the respondents represented from 10-13 years of age. Majority of the girls completed secondary level of education. Average monthly family income was 12226 BDT. Majority of the respondents (84.61\%) had good awareness on age of marriage. About $15.38 \%$ of the study population had fair awareness on age to be pregnant whether majority of the respondents (84.61\%) had good awareness.
\end{abstract}

Keywords: Awareness; Early Marriage; Rural Area

\section{Introduction}

Early marriage has association with poor social and physical outcomes not only for young women but also their offspring [1]. Evidence suggests that girls who marry as adolescents attain lower schooling levels, have lower social status in their husbands' families, report less reproductive control and suffer higher rates of maternal mortality and domestic violence [1]. Early marriages are commonly considered a phenomenon restricted to the developing world but the circumstances under which early marriages occur in developing countries. In developing countries, early marriage is highly prevalent across Sub-saharan Africa and South Asia [2-4]. In settings such as Bangladesh, traditional customs that sanction adolescent marriage are frequently blamed for low female schooling attainment because they raise the opportunity cost of educating girls. Early marriage is an issue of significant concern to policymakers and human rights advocates. Governments in developing countries face increasing pressure to eradicate the practice with legal sanctions against parents who marry daughters before a standard age of consent. This study was carried out to assess awareness level on early marriage for girls in rural Bangladesh.

\section{Methodology}

This was an epidemiological study conducted in cross cut way to assess awareness level on early marriage among conveniently selected 300 adolescent girls in Sirajgonj district. Data were collected through structured questionnaire by face to face interview which was pre tested earlier in an area similar to study area before finalizing the same. After data collection, it was edited and cleaned, coding, grouping and regrouping and summarized before analysis. The data analysis was processed and analyzed by SPSS version 17.0 including descriptive statistic using mean, standard deviation, percentage, minimum, maximum value to describes a dependent variable and independent variable. Chi-square test, Fisher's exact test was used to describe the association between independent variable and dependent variable. Average monthly family income was 12226 BDT. It was found that one third (38.3\%) respondent's monthly family income was 10001-15000 BDT followed by $28.7 \%$ had $5001-10000$ BDT, $18.7 \%$ had $15001-20000$ BDT and 10.3 had their income $\leq 5000$ BDT. Note: For each correct answer the score was one. Then accordingly the respondents were categorized in different groups as below: Good $=$ Score $\geq 3$, Fair $=$ Score 2, Poor $=$ Score 1

A) Table 1 shows that $15.38 \%$ of the study population had fair awareness about age of early marriage whether majority of the respondents (84.61\%) had good awareness. Note: For each correct answer the score was one. Then accordingly the 
respondents were categorized in different groups as below: Good $=$ Score $\geq 3$, Fair $=$ Score 2 , Poor $=$ Score 1

Table 1: Awareness level on age of early marriage $(n=300)$.

\begin{tabular}{|c|c|c|}
\hline Awareness level & Frequency & Percentage \\
\hline Good & 254 & 84.61 \\
\hline Fair & 46 & 15.38 \\
\hline Total & 300 & 100.00 \\
\hline
\end{tabular}

B) Table 2 shows that $15.38 \%$ of the study population had fair awareness on age to be pregnant whether majority of the respondents (84.61\%) had good awareness.

Table 2: Awareness level about age to be pregnant $(n=300)$.

\begin{tabular}{|c|c|c|}
\hline Awareness level & Frequency & Percentage \\
\hline Good & 254 & 84.61 \\
\hline Fair & 46 & 15.38 \\
\hline Total & 300 & 100.00 \\
\hline
\end{tabular}

\section{Discussion}

The United Nations estimates that in 2011, one in three women aged twenty to twenty-four had married under the age of 18 [5]. An additional 142 million girls are estimated to be married as children if eorts are not put in place to delay early marriage. Early marriage is not only a human rights violation but also acts as a threat to the stability of countries where it is prevalent. The potential adverse consequences of early marriages on girls and women are alarming. Marrying early is associated with early childbirth, which occurs before physical growth and development is complete leading to numerous pregnancy related health concerns for young mother and child. Marriage also deters education where young girls drop out to give birth and devote time to childcare. The husband-wife age gap is of immense importance in determining the relationship between husband and wife where a large gap leaves young girls with less decision-making power. This also results in the increase in probability of violence upon girls within that household. These families are usually poor and tend to remain poor [6]. This study found that majority of the respondents had good awareness on age of marriage. About $15.38 \%$ of the study population had fair awareness on age to be pregnant whether majority of the respondents had good awareness (Table 3). Top ranking countries such as Nigeria and Bangladesh have early marriage incidences as high as $76 \%$ and $65 \%$, respectively [7]. Pakistan ranks number 6 in the top 10 countries with the highest absolute number of early marriages [5]. Most of the adverse consequences of early marriages are related to girls. Hence, literature at large surrounds itself around this population sub-group. In South Asia, girls' marriages are decided upon by parents with usually little to none participation of the daughters (Table 4). Tribal influences, culture and religious justifications exist for marrying girls early. Also part of the decision are marital payments that tend to increase as the girls marry later and also induce early marriages. Any policy that attempts to deter girls' marriage age in South Asia, must target parents' and society belief structures (Table 5).

Table 3: Age group distribution of the respondents $(n=300)$.

\begin{tabular}{|c|c|c|}
\hline Age group & Frequency & Percentage \\
\hline $10-13$ & 150 & 50.0 \\
\hline $14-16$ & 92 & 30.7 \\
\hline $17-19$ & 58 & 19.3 \\
\hline Total & 300 & 100.00 \\
\hline
\end{tabular}

Table 4: Distribution of the respondent by educational level $(n=300)$.

\begin{tabular}{|c|c|c|}
\hline Level of Education & Frequency & Percentage \\
\hline Illiterate & 4 & 1.3 \\
\hline Only can sign & 42 & 14.0 \\
\hline Can write \& read & 15 & 5.0 \\
\hline Primary & 109 & 36.33 \\
\hline Secondary & 90 & 30.0 \\
\hline SSC \& Higher & 40 & 13.3 \\
\hline Total & 300 & 100.00 \\
\hline
\end{tabular}

Table 5: Monthly family income of the study subjects $(n=300)$.

\begin{tabular}{|c|c|c|}
\hline Monthly family income in BDT & Frequency & Percentage \\
\hline$\leq 5000$ & 31 & 10.3 \\
\hline $5001-10000$ & 86 & 28.7 \\
\hline $10001-15000$ & 115 & 38.3 \\
\hline $15001-20000$ & 56 & 18.7 \\
\hline$\geq 20001$ & 12 & 4.0 \\
\hline Mean \pm SD & $12226 \pm 5787.366$ & \\
\hline Total & 300 & 100.00 \\
\hline
\end{tabular}

\section{Conclusion}

Awareness level on early marriage have to be increased through proper health education programme. Parents have to be engaged in this pragramme.

\section{Refernces}

1 Adioetomo Sri M (1983) Age at marriage and fertility in Java-Bali: A Question of natural or controlled fertility. Indonesian Journal of Demography10: 49-72.

2 Singh S, Samara R (1996) Early Marriage among Women in Developing Countries. International Family Planning Perspectives p. 22.

3 Williamson J (2014) Giving what we can. Child Marriage: Causes, Effects and Interventions.

4 Choe M, Thapa S, Mishra V (2005) Early Marriage and Early Motherhood in Nepal. Journal of Biosocial Science 37:143-162.

5 Vogelstein R (2013) Ending Child Marriage, How elevating the status of girls advances US foreign policy objectives", Council on Foreign Relations, USA.

6 Jensen R, Thonrton R (2006) Early Female Marriage in the Developing World. Gender and Development 11: 2.

7 (2015) UNICEF State of the World's Children, USA. 
This work is licensed under Creative Commons Attribution 4.0 License DOI: 10.19080/JOJPH.2018.04.555626
Your next submission with Juniper Publishers will reach you the below assets

- Quality Editorial service

- Swift Peer Review

- Reprints availability

- E-prints Service

- Manuscript Podcast for convenient understanding

- Global attainment for your research

- Manuscript accessibility in different formats

( Pdf, E-pub, Full Text, Audio)

- Unceasing customer service

Track the below URL for one-step submission https://juniperpublishers.com/online-submission.php 